\title{
Indonesian Version of the Fear of COVID-19 Scale: Validity and Reliability
}

Mohd Amiruddin Mohd Kassim, ${ }^{1}$ Friska Ayu ${ }^{2, *}$ Assis Kamu, ${ }^{1}$ Nicholas Tze Ping Pang, ${ }^{1}$ Chong Mun Ho, ${ }^{1}$ Hafid Algristian, ${ }^{2}$ Moch Sahri, ${ }^{2}$ Nurfarah Lydia Hambali, ${ }^{1}$ Azizan Omar ${ }^{1}$

\section{Abstract}

Background and Objective: The Fear of COVID-19 Scale (FCV-19S) is a seven-item unidimensional scale assessing the severity of COVID-19 concerns. A translation and validation of the FCV-19S in Bahasa Indonesia language was expedited in view of the worrying trends of COVID-19 in Indonesia as well as its psychological squeal.

Methods: Formal WHO forward and backward translation sequences were applied in translating the English FCV-19S into Bahasa Indonesia. Indonesian university participants were recruited via convenience sampling online using snowball methods. The reliability and validity of the Indonesian FCV-19S was psychometrically evaluated by applying confirmatory factor analysis and Rasch analysis in relation to sociodemographic variables and response to the depression, anxiety, and stress components of the Indonesian version of DASS-21. The sample consisted of 434 Indonesian participants.

Results: The Cronbach $\alpha$ value for the Indonesia FCV-19-I was 0.819 indicated very good internal reliability. The results of the confirmatory factor analysis showed that the unidimensional factor structure of the FCV19S fitted well with the data. The FCV-19-I was significantly correlated with anxiety $(r=0.705, \mathrm{p}<0.001)$ subscales of DASS- 21 . The FCV19-I's properties tested using Rasch analysis were also satisfactory, although three items in FCV-19-I were not able to be tested.

Conclusion: Hence, the Indonesian FCV-19-I is valid and reliable, with robust psychometric properties from classical and modern psychometric methods. It can be a valuable and useful tool in identifying and responding to psychological distress caused by COVID- 19 .

Keywords: Indonesia, Fear of COVID-19, COVID-19, Rasch analysis, DASS-21

Correspondence Email: friskayuligoy@unusa.ac.id

${ }^{l}$ Department of Community and Family Medicine, Faculty of Medicine and Health Sciences, Universiti Malaysia Sabah, Kota Kinabalu, Sabah, Malaysia

${ }^{2}$ Universitas Nahdlatul Ulama Surabaya, Jl. Jemursari 51-57,60237 Surabaya,Indonesia.

Received: 19/10/2020

Accepted: 03/12/2020 
Introduction

The Coronavirus Diseases 2019 (COVID-19) pandemic, first reported in China in December 2019, has resulted in high levels of displacement, worldwide psychological panic, and has had huge knock on effects on employment, people's livelihood, and the travel and aviation industry in general (Nicola, M. et. al., 2020; Ho, C.S.H. et. al., 2020). Despite South East Asia region reporting its first case back in January 2020, Indonesia as the largest country in the region only reported its first case on $2^{\text {nd }}$ March 2020. Within a short space of time, COVID-19 spread to numerous provinces, with Jakarta as the epicenter. As of $8^{\text {th }}$ June 2020 , Indonesia recorded 32,033 total cases and 1,883 total deaths, translating to a mortality rate of $5.88 \%$, ranking among the highest in the region. However, Indonesia also had one of the lowest coronavirus testing rates; only 36 in one million were tested as compared to Singapore which tested 6,666 people per million. Thus, the true number of cases in Indonesia has been underestimated. As part of its response, the Indonesian government implemented Pembatasan Sosial Berskala Besar (PSBB), a large-scale social distancing policy. However, the widespread infection and the social distancing policy are uncharted territory for most Indonesians, especially in quarantined situations e.g. university students (Mukhsam, M.H. et. al., 2020; Salvaraji, L. et. al., 2020). This appears to have resulted in numerous psychological consequences, including fear and stigma (Lin. C.Y. et. al., 2020). The fear of contracting the infection has impacted many individuals as well as their families (Harper, C.A. et. al., 2020).

It is crucial to forge methods of measuring distress that are quantitative in nature to allow more objective and focused assessment. This allows for better impact analysis, improving implementation of educational material or preventative management (Pakpour, A.H. et. al., 2020). There are limited psychological scales available in Bahasa Indonesia, especially for fear of COVID-19 which is a new construct. A Persian and English Fear of COVID-19 scale (FCV-19) has been developed, which is a series of 7 questions scored on a 5-point Likert scale, proving to be a concise scale suitable for busy clinical settings (Ahorsu, D.K. et. al., 2020). This scale has been translated and validated into multiple languages, including Arabic, Turkish, Russian, Bangladeshi, Italian and Malay (Alyami, M. et. al., 2020; Satici, B. et. al., 2020; Reznik, A. et. al., 2020; Sakib, N. et. al., 2020; Soraci, P. et. al., 2020; Pang, N.T.P. et. al., 2020). With high mortality and low detection rates in the Indonesian setting, it is imperative the FCV-19 be translated and validated into what is essentially the language of 200 million people, using rigorous statistical models.

\section{Materials and methods}

\section{Ethical Approval}

Ethical approval was obtained from the Universiti Malaysia Sabah Medical Research Ethics Committee \& Universitas Nahdlatul Ulama Surabaya Medical Ethics Committee prior to commencement of this project. All participants were presented with participant information sheet in the first page of the Google Form and have the right to refuse to participate without penalty, shall they decline. All participants in this study provided informed consent. 


\section{Methodology}

Standard WHO guidelines were employed for FCV-19 validation. First, two independent experts: one as a content expert who is familiar with COVID-19 and bilingual in English and Bahasa Indonesia; and one as a language expert who is more familiar with Bahasa Indonesia; forward translated the FCV-19 from English to Bahasa Indonesia. Then, two separate individuals serving as content and language experts respectively, who were blind to the original translation, translated the Bahasa Indonesia version back into English. The two versions were compared and analyzed for major inconsistencies, and a revised version was hence produced. The revision was pilot tested in 20 Bahasa Indonesia-speaking individuals. Once further inconsistencies and incongruence with the original English version were rectified, a final Bahasa Indonesia translation was then produced.

The validation study was performed in a few universities in Surabaya, Indonesia. Convenience sampling was employed, and snowball methods were used to recruit samples. Google Forms were used with incorporated consent forms, sociodemographic questionnaires and research instruments, due to the inherent limitations for face to face data collection caused by the Indonesian PSBB lockdown. Snowball recruitment was performed utilising student and staff mailing lists. A sample size of 400 was planned to be recruited to facilitate the use of factor analysis with classical test theory methods, as it was considered a fair sample size for the purpose of factor analysis (Voorhis C.R.W.V. et. al., 2007). Each participant was given a questionnaire containing three sections to fill in as follows.

\section{Sociodemographic Questionnaire:}

This was a brief questionnaire requesting for age, gender, education level, current occupation, location where participant was staying during the pandemic and marital status.

\section{Fear of COVID-19 scale}

The English FCV-19 was administered concurrently with the fresh Bahasa Indonesia FCV19-I. The English Fear of COVID-19 scale consists of seven items (e.g., "I cannot sleep because I am worried about getting coronavirus-19"), scored on a five-item Likert point response ranging from 1 (strongly disagree) to 5 (strongly agree). The possible scores range from 7 to 35. The higher the score, higher the level of fear of COVID-19 (Ahorsu, D.K. et. $a l ., 2020)$, the original English scale has good internal reliability (Cronbach alpha= 0.82) and test-retest reliability (ICC $=0.72$ ), with satisfactory evaluations of other properties based on classical test theory and Rasch model analysis. The psychometric properties of the Bahasa Indonesia FCV-19-I are presented in the "Results" section.

\section{DASS-21 scale}

The DASS-21 (Lovibond, S.H. et. al., 1995) is self-reported, assesses the level of emotional distress (depression, anxiety and stress). It consists of 21 items that capture information about three separate feels: depression (e.g., "I couldn't seem to experience positive feeling"), anxiety (e.g., "I was aware of dryness of my mouth") and stress (e.g., "I found it hard to wind down"). 
The 21 items were rated on a four-point Likert scale ranging from 0 (did not apply to me at all over the last week) to 3 (applied to me very much or most of the time over the past week), with higher scores corresponding to greater severity. In the current study, the Indonesian version of Depression, Anxiety and Stress Scale 21 (DASS-21) was used.

\section{Data Analysis}

To assess the validity and reliability of FCV-19-I, classical test theory (CTT) (Novick, M.R., 1966) and Rasch measurement theory (RMT) (Hobart, J., 2009) were concurrently employed. Subsequently, validity and reliability tests were divided into two levels; which are scale level (the analyses were done at scale level) and item level (the analyses were done at item level). For the scale level, the CCT's methods employed were internal consistency measure using Cronbach's alpha, McDonald's omega, greatest lower bound, test-retest reliability using Pearson correlation test (Bahasa Indonesia version versus English version), average variance extracted (AVE), composite reliability, standard error of measurement, concurrent validity (fear of COVID-19 scale versus depression scale, anxiety scale, and stress scale), while the RMT's methods used were item and person separation reliability, and item and person separation index. On the other hand, for the item level, the CTT's methods employed were item-item correlation and item-total correlation, while the RMT's methods used were infit and outfit mean square (MnSq) and differential item functioning (DIF) to test the measurement invariance across gender. IBM SPSS 24.0 was used to run the CTT, while the RMT was run using jMetrik 4.1.1. The McDonald's omega and the greatest lower bound were calculated using JAPS. The original version (i.e. English version) (Ahorsu, D.K. et. al., 2020) and the Bahasa Indonesia version of the fear of COVID-19 is as presented in Table 1.

Table 1: The Original English Version the Bahasa Indonesia Version of the FCV-19

\begin{tabular}{lll}
\hline Item & The original English version & The Bahasa Indonesia version \\
\hline Item 1 & I am most afraid of COVID-19 & $\begin{array}{l}\text { Saya sangat takut terhadap Virus Corona } \\
\text { (COVID-19) }\end{array}$ \\
Item 2 & $\begin{array}{l}\text { It makes me uncomfortable to think } \\
\text { about COVID-19 }\end{array}$ & $\begin{array}{l}\text { Saya merasa tidak nyaman apabila } \\
\text { memikirkan tentang virus corona (COVID-19) }\end{array}$ \\
Item 3 & $\begin{array}{l}\text { My hands become clammy when I } \\
\text { think about COVID-19 }\end{array}$ & $\begin{array}{l}\text { Tangan saya berkeringat ketika memikirkan } \\
\text { tentang virus corona (COVID-19) }\end{array}$ \\
Item 4 & $\begin{array}{l}\text { I am afraid of losing my life because } \\
\text { of COVID-19 }\end{array}$ & $\begin{array}{l}\text { Saya takut kehilangan hidup saya dikarenakan } \\
\text { terpapar oleh virus corona (COVID-19) }\end{array}$ \\
Item 5 & $\begin{array}{l}\text { When watching news and stories } \\
\text { about Corona Viruses-19 on social } \\
\text { media, I become nervous or anxious }\end{array}$ & $\begin{array}{l}\text { Saya merasa gugup dan khawatir apabila saya } \\
\text { mendengar tentang virus corona (COVID-19) } \\
\text { melalui siaran berita dan media sosial }\end{array}$ \\
Item 6 & $\begin{array}{l}\text { I cannot sleep because I am } \\
\text { worrying about getting COVID-19 }\end{array}$ & $\begin{array}{l}\text { Saya tidak bisa tidur nyenyak karena khawatir } \\
\text { terinfeksi virus corona (COVID-19) }\end{array}$ \\
Item 7 & $\begin{array}{l}\text { My heart races or palpitates when I } \\
\text { think about getting COVID-19 }\end{array}$ & $\begin{array}{l}\text { Jantung saya berdebar debar memikirkan } \\
\text { tentang virus corona (COVID-19) }\end{array}$ \\
\hline
\end{tabular}




\section{Results}

The sociodemographic of the respondents are displayed in Table 2. The majority of the participants were single, of female gender, students rather than employed, and the highest education being high school. Half of the participants resided in Surabaya during the pandemic, while another half was outside Surabaya. The mean age of the participants was 26 years old. Skewness and kurtosis for all 7 items on the Indonesian Fear of COVID-19 scale was acceptable as in the range of -0.883 to 2.608 , and -1.056 to 6.383 respectively.

Table 2: The respondents' background information $(n=434)$

\begin{tabular}{|c|c|c|c|c|}
\hline Background & Category & $\mathbf{N}$ & $\%$ & Mean \\
\hline Age & & & & 26 years old \\
\hline \multirow{2}{*}{ Age category } & 25 years and below & 291 & $67.10 \%$ & \\
\hline & More than 25 years old & 143 & $32.90 \%$ & \\
\hline \multirow{2}{*}{ Gender } & Male & 108 & $24.90 \%$ & \\
\hline & Female & 326 & $75.10 \%$ & \\
\hline \multirow{5}{*}{ Education level } & High school & 275 & $63.40 \%$ & \\
\hline & Diploma & 20 & $4.60 \%$ & \\
\hline & Bachelor degree & 44 & $10.10 \%$ & \\
\hline & Master degree & 82 & $18.90 \%$ & \\
\hline & Doctoral Degree & 13 & $3.00 \%$ & \\
\hline \multirow{5}{*}{ Job } & Staff & 26 & $6.00 \%$ & \\
\hline & Educational Staff & 13 & $3.00 \%$ & \\
\hline & Lecturer & 94 & $21.70 \%$ & \\
\hline & Librarian/ Laboratory Assistant & 11 & $2.50 \%$ & \\
\hline & Student & 290 & $66.80 \%$ & \\
\hline \multirow{2}{*}{ City } & Surabaya & 217 & $50.00 \%$ & \\
\hline & Others & 217 & $50.00 \%$ & \\
\hline \multirow{2}{*}{ Marital status } & Single & 321 & $74.00 \%$ & \\
\hline & Married & 113 & $26.00 \%$ & \\
\hline
\end{tabular}

From Table 3, it is noted that none of the participants selected 'strongly agree' option in item $3,6 \& 7$. Otherwise, the results of the Pearson correlation coefficient show that almost all the inter-item correlation coefficients were higher than 0.3 (Table 4). This implies that the instrument has an acceptable validity (Cohen, J., 1992). Furthermore, there was only one corrected item-total correlation coefficient with a value of less than 0.5 (Table 5). This concurs with recommendations that in an empirical approach, as a rule of thumb, if the score of the item-to-total correlations is more than 0.50 and the inter-item correlations exceed 0.30 , the construct validity is satisfied (John, P.R. et. al., 1991). 
Table 3: The respondent's choices

\begin{tabular}{lccccccccccc}
\hline Item & Strongly disagree & \multicolumn{2}{c}{ Disagree } & \multicolumn{2}{c}{ Neutral } & \multicolumn{2}{c}{ Agree } & \multicolumn{3}{c}{ Strongly agree } \\
\hline & Count & $\%$ & Count & $\%$ & \multicolumn{2}{c}{ Count } & $\%$ & Count & $\%$ & Count & $\%$ \\
Item 1 & 22 & $5.10 \%$ & 39 & $9.00 \%$ & 106 & $24.40 \%$ & 224 & $51.60 \%$ & 43 & $9.90 \%$ \\
Item 2 & 110 & $25.30 \%$ & 132 & $30.40 \%$ & 99 & $22.80 \%$ & 72 & $16.60 \%$ & 21 & $4.80 \%$ \\
Item 3 & 281 & $64.70 \%$ & 91 & $21.00 \%$ & 59 & $13.60 \%$ & 3 & $0.70 \%$ & 0 & $0.00 \%$ \\
Item 4 & 53 & $12.20 \%$ & 44 & $10.10 \%$ & 89 & $20.50 \%$ & 219 & $50.50 \%$ & 29 & $6.70 \%$ \\
Item 5 & 206 & $47.50 \%$ & 74 & $17.10 \%$ & 113 & $26.00 \%$ & 40 & $9.20 \%$ & 1 & $0.20 \%$ \\
Item 6 & 199 & $45.90 \%$ & 132 & $30.40 \%$ & 90 & $20.70 \%$ & 13 & $3.00 \%$ & 0 & $0.00 \%$ \\
Item 7 & 366 & $84.30 \%$ & 49 & $11.30 \%$ & 18 & $4.10 \%$ & 1 & $0.20 \%$ & 0 & $0.00 \%$ \\
\hline
\end{tabular}

Table 4: The item-item correlation matrix $(n=434)$

\begin{tabular}{lcccccc}
\hline Item & Item 1 & Item 2 & Item 3 & Item 4 & Item 5 & Item 6 \\
\hline Item 2 & $0.440^{* *}$ & & & & & \\
Item 3 & $0.286^{* *}$ & $0.501 * *$ & & & & \\
Item 4 & $0.618^{* *}$ & $0.321^{* *}$ & $0.319 * *$ & & & \\
Item 5 & $0.381^{* *}$ & $0.546^{* *}$ & $0.452^{* *}$ & $0.444 * *$ & & \\
Item 6 & $0.404 * *$ & $0.489^{* *}$ & $0.346^{* *}$ & $0.430 * *$ & $0.399 * *$ & \\
Item 7 & $0.122^{*}$ & $0.523 * *$ & $0.536 * *$ & $0.206 * *$ & $0.396^{* *}$ & $0.376 * *$ \\
\hline
\end{tabular}

Table 5: The corrected item-total correlation $(n=434)$

\begin{tabular}{lcc}
\hline Item & Corrected Item-Total Correlation & Item exclusion or retention \\
\hline Item 1 & 0.565 & Retained \\
\hline Item 2 & 0.650 & Retained \\
\hline Item 3 & 0.550 & Retained \\
\hline Item 4 & 0.559 & Retained \\
\hline Item 5 & 0.622 & Retained \\
Item 6 & 0.575 & Retained \\
Item 7 & 0.489 & Retained \\
\hline
\end{tabular}

All the psychometric measures' results as shown in Table 6 have confirmed the validity and reliability of FCV-19-I as all the values have passed the suggested cut-off except for AVE. Additionally, at the item level, all the factor loadings were higher than 0.3 which means that the items are important (Pituch, K.A. et. al., 2015) as presented in Table 7. All the communalities were also closer 1 except for Item 6 suggesting that extracted factor explains more of the variance of an individual item. The FCV-19-I's properties tested using Rasch analysis were also satisfactory where infit MnSq values were between 0.85 and 1.07, outfit $\mathrm{MnSq}$ values were between 0.85 and 1.12. These item fit statistics show that each item meets the unidimensional requirement of a Rasch model as all the values within 0.5-1.5 range (Wright, B.D. et. al., 1994). The most difficult item was Item 5 (i.e. the highest value) and the easier item was Item 1 (i.e. the lowest value). There was also no substantial DIF found across gender since all the DIF contrast values were less than 0.5 (Shih, C.L., et. al., 2009). 
Table 6: Psychometric properties for the Indonesia version of the fear of COVID-19 scale at the scale level $(n=434)$

\begin{tabular}{|c|c|c|c|}
\hline $\begin{array}{l}\text { Psychometric } \\
\text { method }\end{array}$ & Psychometric measure & Result & $\begin{array}{l}\text { Suggested } \\
\text { cut-off }\end{array}$ \\
\hline \multirow{9}{*}{ CTT } & Internal consistency measure using Cronbach's alpha & 0.819 & $>0.7$ \\
\hline & Internal consistency measure using McDonald's omega & 0.829 & $>0.7$ \\
\hline & Internal consistency measure using Greatest lower bound & d 0.882 & $>0.7$ \\
\hline & Test-retest reliability & $0.997 * *$ & See Note \\
\hline & Average variance extracted (AVE) & 0.420 & $>0.5$ \\
\hline & Composite reliability & 0.820 & $>0.7$ \\
\hline & $\begin{array}{l}\text { Concurrent validity (Fear of COVID-19 scale versus } \\
\text { Depression scale) }\end{array}$ & $0.554 * *$ & See Note \\
\hline & $\begin{array}{l}\text { Concurrent validity (Fear of COVID-19 scale versus } \\
\text { Anxiety scale) }\end{array}$ & $0.705 * *$ & See Note \\
\hline & $\begin{array}{l}\text { Concurrent validity (Fear of COVID-19 scale versus } \\
\text { Stress scale) }\end{array}$ & $0.530 * *$ & See Note \\
\hline \multirow{4}{*}{ RMT } & Item separation reliability & 0.997 & $>0.7$ \\
\hline & Item separation index & 19.261 & $>2$ \\
\hline & Person separation reliability & 0.811 & $>0.7$ \\
\hline & Person separation index & 2.072 & $>2$ \\
\hline
\end{tabular}

*Correlation is significant at the 0.05 level (two-tailed test);

** Correlation is significant at the 0.01 level (two-tailed test);

Note: Correlation coefficients of $<0.25$ were considered as small; $0.25-0.50$ as moderate; $0.50-0.75$ as good; and $>0.75$ as excellent

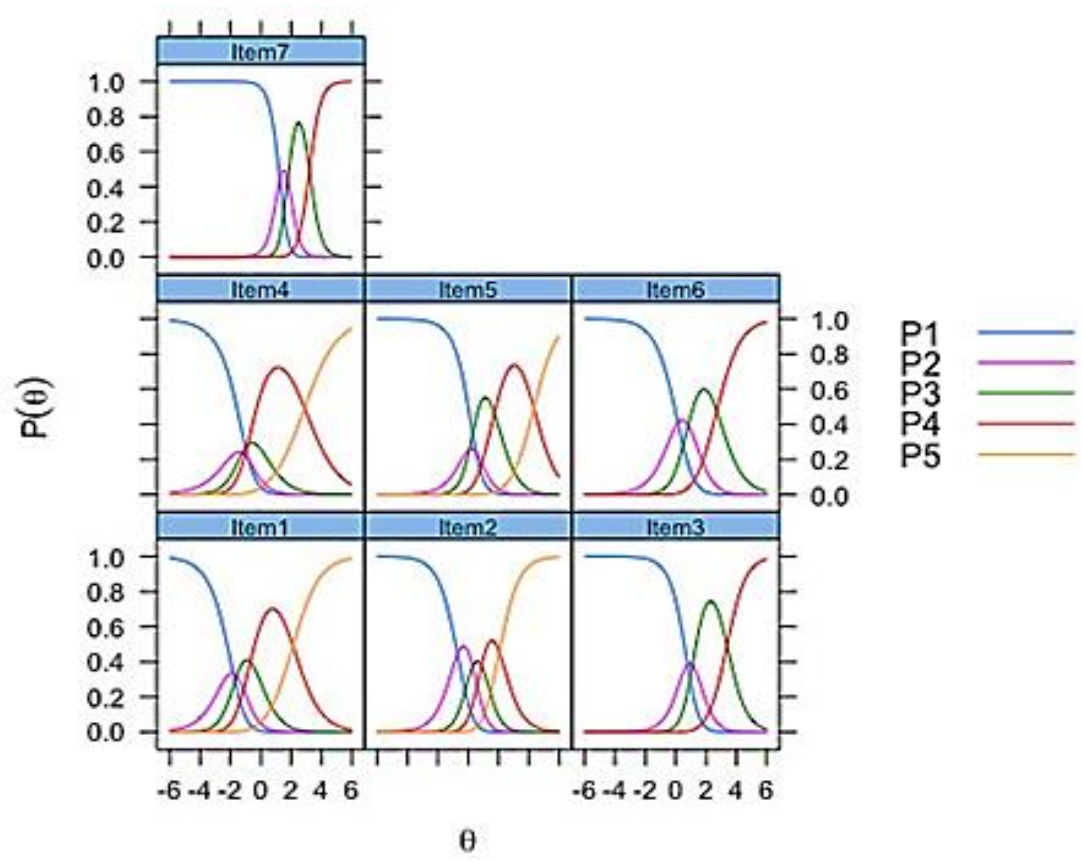

Figure 1: Item traces lines 
Table 7: Psychometric properties of Indonesia version of the fear of COVID-19 scale at the item level $(n=434)$

\begin{tabular}{|c|c|c|c|c|c|c|}
\hline Item & $\begin{array}{l}\text { Factor } \\
\text { loading* }\end{array}$ & Communalities & $\begin{array}{c}\text { Infit } \\
\text { MnSq }\end{array}$ & $\begin{array}{l}\text { Outfit } \\
\text { MnSq }\end{array}$ & Difficulty & $\begin{array}{c}\text { DIF contrast } \\
\text { across gender }^{\text {a,b }}\end{array}$ \\
\hline Item 1 & 0.300 & 0.776 & 0.85 & 0.97 & -1.65 & -0.06 \\
\hline Item 2 & 0.789 & 0.663 & 1.07 & 1.12 & 0.44 & -0.02 \\
\hline Item 3 & 0.789 & 0.622 & ---------. & 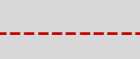 & --Dropped-- & ------------. \\
\hline Item 4 & 0.336 & 0.742 & 1.00 & 1.08 & -0.89 & 0.20 \\
\hline Item 5 & 0.673 & 0.558 & 0.91 & 0.85 & 2.10 & 0.05 \\
\hline Item 6 & 0.577 & 0.499 & --------- & 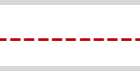 & -Dropped-- & 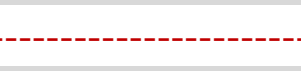 \\
\hline Item 7 & 0.841 & 0.753 & & & --Dropped--. & - \\
\hline
\end{tabular}

Item 3, $6 \& 7$ dropped due to unobserved categories mainly 'Strongly agree' as per Table 3; $\mathrm{MnSq}$ is mean square error, DIF is differential item functioning;

*Extraction method: Oblimin rotation with Kaiser Normalization;

${ }^{a}$ DIF contrast $>0.5$ indicates substantial DIF;

${ }^{\mathrm{b}}$ DIF contrast across gender $=$ difficulty for males (reference group) - difficulty for females (focal group).

Positive values indicate items that are differentially easier for the focal group than the reference group.

Negative values indicate items that are differentially harder for the focal group than the reference group.

Confirmatory factor analysis result also showed acceptable fit, with GFI $=0.870$, $\mathrm{NFI}=0.791, \mathrm{CFI}=0.800$, and $\mathrm{SRMR}=0.088$. GFI more than 0.85 indicates good fit (Anderson, J.C. et. al., 1984), while NFI of 0.7-0.9 is considered as acceptable fit, with the ideal value is more than 0.9 (Fattah, S.M.A.E., 2010). CFI of 0.8-0.9 indicates acceptable fit, while CFI value of $>0.90$ is accepted as good fit (Browne, M.W. et. al., 1993). On the other hand, $\mathrm{SRMR}<0.90$ is considered as acceptable fit, with the value of $<0.80$ considered as ideal fit (Hu, L.T. et. al., 1999). In ultimate the correlation diagram for Item 1 to 7 have shown in Figure 1 above.

\section{Discussion}

This study applied Rasch analysis in order to evaluate the psychometric characteristic of Fear of COVID-19 Scale (FCV-19) Indonesian version. However, as item 3, item 6 and item 7 had no 'strongly agree' response, Rasch analysis for the respective items were not able to be done. Nevertheless, the FCV-19-I demonstrates acceptable psychometric properties which render it valuable for use in assessing the brand new construct of COVID-19 related concerns and fears. With such psychometric properties, it can be used on a larger national scale in Indonesia to capture associations between fear and other related psychological process variables as part of larger studies exploring the psychological sequelae of COVID-19 on the Indonesian population. 
The correlations with associated constructs in validated scales of similar language are noticeable in Anxiety subscale of the DASS, with correlations of .705. This suggests that more research needs to be performed to explore this finding further, as it is crucial to investigate how similar anxiety as encoded in the existing DSM-5 is to the construct of fear of COVID-19, as there are ultra-brief psychological interventions that can assist so (Pang, N.T.P. et. al., 2020). The findings of these study mirror the Malay version of the Fear of COVID-19 Scale, which showed strong correlations with anxiety (Pang, N.T.P. et. al., 2020); this means that relationships between behavioral explanations and anxiety are largely viable (Eugene K.B.Y. et. al., 2020).

The main limitations are that this study used predominantly university staff and students in Surabaya. This is an unavoidable limitation as PSBB significantly restricts face to face collection of data for all psychometrics research, which has significantly constrained research work. Secondly, the sample size of 434 may not be sufficiently representative, due to difficulties in recruiting larger samples amid the restrictions; hence a sufficient number to perform factor analysis was recruited. Besides that, the content of item 3, item 6 and item 7 in the Bahasa Indonesia language may not yield polarized or strong answers in the language, as the translated version did not yield any 'strongly agree' responses. Apart from that, this study is also limited by difficulty in performing concurrent validity with other scales measuring anxiety, as there is no equivalent of a phobia scale validated into Indonesian. Lastly, there is also possibility of cross-language correlation which might affect the way participants answer the scales in both Bahasa Indonesia and English language. As this study was done at the height of COVID-19, there was urgent need to expedite the process to translate and validate the scale, so it can be further utilized in the bigger population.

Across multiple measures, it retains reasonable internal consistency, with Cronbach's alpha of 0.819 , McDonald's omega of 0.829 , and greatest lower bound of .882; acceptable construct validity based on the accepted score of the item-to-total correlations $>0.50$ and the inter-item correlations > 0.30; good test-retest and composite reliability; good item separation reliability and item separation index based on Rasch analysis; reasonable concurrent validity based on reasonable correlations with the depression, anxiety, and stress components of the DASS-21; and Rasch analyses at the item level were deemed acceptable. When comparing with the existing validated instruments that are currently available, the single factor structure and good factor loadings for all items showed that the items are generally relevant.

\section{Conclusion}

In conclusion, this study proved that FCV-19-I is a psychometrically sound instrument, validated by classical and modern statistical approach. As Indonesia facing ongoing battle against COVID-19, it is hoped that this scale able to provide useful insight to psychological distress suffered by Indonesians; an aspect that might be overlooked in this testing times, and perhaps provide an impetus for a proper intervention much needed in the community. Further validation study in a more representative sample is recommended. 


\section{Conflict of Interest}

All authors declared no conflict of interest. No funding received.

\section{Ethical Approval}

All procedures followed were in accordance with the ethical standards of the responsible committee on human experimentation (institutional and national) and with the Helsinki Declaration of 1975, as revised in 2000 (5).

\section{Consent}

Informed consent was obtained from all participants for being included in the study.

\section{References}

Ahorsu, D.K., Lin, C.Y., Imani, V., Saffari, M., Griffiths, M.D., Pakpour, A.H. (2020). The Fear of COVID-19 Scale: Development and Initial Validation. Int. J. Ment. Health Addict., 1-9. https://link.springer.com/article/10.1007\%2Fs11469-020-00270-8

Alyami, M., Henning, M., Krägeloh, C.U., Alyami H. (2020). Psychometric Evaluation of the Arabic Version of the Fear of COVID-19 Scale. Int. J. Ment. Health Addict., 1-14. https://link.springer.com/article/10.1007\%2Fs11469-020-00316-X

Anderson, J.C., Gerbing, D.W. (1984). The effect of sampling error on convergence, improper solutions, and goodness-of-fit indices for maximum likelihood confirmatory factor analysis. Psychometrika, 49, 155-173. https://link.springer.com/article/10.1007/BF02294170

Browne, M.W., Cudeck, R. (1993). Alternative Ways of Assessing Model Fit. In: Bollen, K.A., Long, J.S. (Eds.), Testing Structural Equation Models, pp. 136-162. Sage publications, Thousand Oaks. https://journals.sagepub.com/doi/10.1177/0049124192021002005

Cohen, J. (1992). Statistical Power Analysis, Curr. Dir. Psychol. Sci., 1(3), 98-101. https://doi.org/10.1111\%2F1467-8721.ep10768783

Eugene K.B.Y., Nicholas, P.T.P., Shoesmith, W.D., Sandi, J., Hadi, N.M.N., Loo, J.L. (2020). The Behaviour Changes in Response to COVID-19 Pandemic within Malaysia, Malays. J. Med. Sci., 27(2), 45-50. http://www.mjms.usm.my/MJMS27022020/05MJMS27022020_OA.pdf

Fattah, S.M.A.E., (2010). Book Review on "Structural Equation Modeling with AMOS: Basic Concepts, Applications, and Programming (2nd Ed.)" J. Appl. Quant. Methods., 5(2), 365-367. http://www.jaqm.ro/issues/volume-5,issue-2/pdfs/review.pdf

Harper, C.A., Satchell, L.P., Fido, D., Latzman, R.D. (2020). Functional Fear Predicts Public Health Compliance in the COVID-19 Pandemic. Int. J. Ment. Health Addict., 1-14. https://link.springer.com/article/10.1007\%2Fs11469-020-00281-5

Ho, C.S.H., Chee, C.Y., Ho, R.C. (2020). Mental Health Strategies to Combat the Psychological Impact of Covid-19 Beyond Paranoia and Panic. Ann. Acad. Med. Singapore., 49(3), 155-160. https://www.annals.edu.sg/pdf/49VolNo3Mar2020/V49N3p155.pdf

Hobart J, Cano S. (2009). Improving the Evaluation of Therapeutic Interventions in Multiple Sclerosis: The Role of New Psychometric Methods. Health Technol. Assess., 13(12):iii, ix-x, 1-177. https://doi.org/10.3310/hta13120

Hu, L.T., Bentler, P.M. (1999). Cutoff Criteria for Fit Indexes in Covariance Structure Analysis: Conventional Criteria Versus New Alternatives. Struct. Equ. Model., 6(1), 1-55. https://www.tandfonline.com/doi/abs/10.1080/10705519909540118 
John, P.R., Phillip, R.S., Lawrence, S.W. (1991). Chapter 1: Criteria for Scale Selection and Evaluation, pp. 1-16, Eds: John, P.R., Phillip, R.S., Lawrence, S.W., Measures of Personality and Social Psychological Attitudes, Academic Press, Elsevier Science, London, UK. http://www.sciencedirect.com/science/article/pii/B9780125902410500058

Lin, C.Y. (2020). Social Reaction toward the 2019 Novel Coronavirus (COVID-19). Soc. Heal. Behav., 3(1), 1-2. https://www.shbonweb.com/article.asp?issn=25899767; year $=2020$; volume $=3$; issue $=1$; spage $=1$; epage $=2$; aulast $=$ Lin

Lovibond, S.H., Lovibond, P.F. (1995). Psychology Foundation of Australia (1995). Manual for the depression anxiety stress scales (2nd ed). Psychology Foundation of Australia, Sydney, N.S.W, Australia.

Mukhsam, M.H., Jeffree, M.S., Pang, N.T.P., Rahim, S.S.S.A., Omar, A., Abdullah, M.S., Lukman, K.A., Giloi, N., Salvaraji, L., Karim, M.R.A., Saupin, S., Tat, Y.B., Hayati, M.F.M., Ibrahim, M.Y., Muhamad, A., Zainudin, S.P. (2020). A University-Wide Preparedness Effort in the Alert Phase of COVID-19 Incorporating Community Mental Health and Task-Shifting Strategies: Experience from a Bornean Institute of Higher Learning, Am. J. Trop. Med. Hyg., 103(3), 1201-1203.

http://www.ajtmh.org/docserver/fulltext/14761645/103/3/tpmd200458.pdf?expires=16083631 36\&id=id\&accname=guest\&checksum=5E025346A9B4E40504ED63FABECADBAF

Nicola M, Alsafi Z, Sohrabi C, Kerwan A, Al-Jabir A, Iosifidis C, Agha, M., Agha, R. (2020). The Socio-Economic Implications of the Coronavirus Pandemic (COVID-19): A Review. Int. J. Surgery., 78, 185-193.

https://www.sciencedirect.com/science/article/abs/pii/S1743919120303162?via\%3Dihub

Novick, M.R. (1966). The axioms and principal results of classical test theory. J. Math Psychol., 3(1), 1-18. https://www.sciencedirect.com/science/article/abs/pii/0022249666900022

Pakpour, A.H., Griffiths, M.D. (2020). The Fear of COVID-19 and its Role in Preventive Behaviors. J. Concurr. Disord., 2(1), 58-63. http://irep.ntu.ac.uk/id/eprint/39561/

Pang, N.T.P., Kamu, A., Hambali, N.L.B., Mun, H.C., Kassim, M.A., Mohamed, N.H., Ayu, F., Rahim, S.S.S.A., Omar, A., Jeffree, M.S. (2020). Malay Version of the Fear of COVID-19 Scale: Validity and Reliability, Int. J. Ment. Health. Addict. 1-10. https://link.springer.com/article/10.1007\%2Fs11469-020-00355-4

Pang, N.T.P., Shoesmith, W.D., Sandi, J., Hadi, N.M.N., Koh, E.B.Y., Lin, L.J. (2020). Ultra Brief Psychological Interventions for COVID-19 Pandemic: Introduction of a Locally-Adapted Brief Intervention for Mental Health and Psychosocial Support Service, Malays. J. Med. Sci., 27(2), 51-56. http://www.mjms.usm.my/MJMS27022020/06MJMS27022020_OA.pdf

Pituch, K.A., \& Stevens, J.P. (2015). Applied Multivariate Statistics for the Social Sciences: Analyses with SAS and IBM's SPSS, pp. 1-814, 6th ed., Routledge. https://doi.org/10.4324/9781315814919

Reznik, A., Gritsenko, V., Konstantinov, V., Khamenka, N., Isralowitz, R. (2020). COVID-19 Fear in Eastern Europe: Validation of the Fear of COVID-19 Scale. Int. J. Ment. Health Addict., 12;16. https://link.springer.com/article/10.1007\%2Fs11469-020-00283-3

Sakib, N., Bhuiyan, A.K.M.I., Hossain, S., Mamun, F.A., Hosen, I., Abdullah, A.H. Sarker, M.A., Mohiuddin, M.S., Rayhan, I., Hossain, M., Sikder, M.T., Gozal, D., Muhit, M., Islam, S.M.S., Griffiths, M.D., Pakpour, A.H., Mamun, M.A. (2020). Psychometric Validation of the Bangla Fear of COVID-19 Scale: Confirmatory Factor Analysis and Rasch Analysis. Int. J. Ment. Health Addict., 1-12. https://link.springer.com/article/10.1007\%2Fs11469-020-00289-x

Salvaraji, L., Rahim, S.S.S.A.; Jeffree, M.S.; Omar, A.; Pang, N.T.P.; Ahmedy, F.; Hayati, F.; Tat, Y.B.; Giloi, N.; Saupin, S.; Muhamad, A.; Zainudin, S.P. (2020). The Importance of High Index of Suspicion and Immediate Containment of Suspected Covid-19 Cases in Institute of Higher Education Sabah, Malaysia Borneo, Malaysian J. Public Health Med., 20(2), 74-83. http://www.mjphm.org/index.php/mjphm/article/view/573 
Satici, B., Tekin, E.G., Deniz, M.E., Satici, S.A. (2020). Adaptation of the Fear of COVID-19 Scale: Its Association with Psychological Distress and Life Satisfaction in Turkey. Int. J. Ment. Health Addict., 1-9. https://link.springer.com/article/10.1007/s11469-020-00294-0

Shih CL, Wang WC. (2009). Differential Item Functioning Detection Using the Multiple Indicators, Multiple Causes Method with a Pure Short Anchor, Appl. Psychol. Meas., 2009, 33(3), 184199. https://journals.sagepub.com/doi/10.1177/0146621608321758

Soraci, P., Ferrari, A., Abbiati, F.A., Fante, E.D., Pace, R.D., Urso, A., Griffiths, M.D. (2020). Validation and Psychometric Evaluation of the Italian Version of the Fear of COVID-19 Scale, Int J Ment Health Addict., 1-10. https://link.springer.com/article/10.1007\%2Fs11469-02000277-1

Voorhis C.R.W.V., Morgan B.L. (2007). Understanding Power and Rules of Thumb for Determining Sample Sizes, Tutor Quant. Methods Psychol., 3(2), 43-50. http://www.tqmp.org/RegularArticles/vol03-2/p043/p043.pdf

Wright, B. D., Linacre, J. M. (1994). Reasonable mean-square fit values. Rasch Meas. Trans., 8(3), 370-371. https://www.rasch.org/rmt/rmt83b.htm 